\title{
Dual Descriptor also reveals the Janus-Faced Behaviour of Diiodine
}

\author{
Jorge Martinez ${ }^{1}$ \\ ${ }^{1}$ Universidad Andres Bello
}

May 5, 2020

\begin{abstract}
The diiodine molecule as Janus-faced ligand was evidenced by Rogachev and Hoffmann [A.Y. Rogachev et al., JACS, 2013, 135, 3262] through an exhaustive investigation based on the Molecular Orbital Theory (MOT), Natural Bond Orbital (NBO), and Energy Decomposition Analysis (EDA). In the present article the same conclusions were attained when applying the dual descriptor (DD or second-order Fukui function) on the same molecule. An advantage of DD lies on the fact of being an orbitalfree descriptor, meaning that it is based only upon total electron density when written in its most accurate operational formula. In addition, the present work is an application of the generalized operational formula of the dual descriptor published in 2016 so allowing to predict the same coordination modes as experimentally known: bent "end-on" and linear "end-on"
\end{abstract}

\section{Hosted file}

IJQC_definite_LaTeX_version_JMartinez.pdf available at https://authorea.com/users/291665/ articles/419091-dual-descriptor-also-reveals-the-janus-faced-behaviour-of-diiodine

\section{Hosted file}

Figure01.eps available at https://authorea.com/users/291665/articles/419091-dual-descriptoralso-reveals-the-janus-faced-behaviour-of-diiodine

\section{Hosted file}

Figure02.eps available at https://authorea.com/users/291665/articles/419091-dual-descriptoralso-reveals-the-janus-faced-behaviour-of-diiodine

\section{Hosted file}

Figure03.eps available at https://authorea.com/users/291665/articles/419091-dual-descriptoralso-reveals-the-janus-faced-behaviour-of-diiodine

\section{Hosted file}

Figure04.eps available at https://authorea.com/users/291665/articles/419091-dual-descriptoralso-reveals-the-janus-faced-behaviour-of-diiodine 